\title{
HISTORY OF MEDICINE-3
}

Hippocrates used to take history of the disease and record the findings of clinical examinations in cronological order. Some of these are still avallable.. His description of a case of Diphtheria is wonderful though the patient died on the 5 th day of the disease.

In a small note book entitled "Concerning the things in surgery"he recorded some interesting observations. For surgeon he suggested that one must make the following arrangements before undertaking actual surgery-Patient. surgeon, his assistants, surgical instruments, light and the position of the patient during oparation. This observation is essential even to day. Besides, he advised to put the patient in such a way so that the site of operation is well lighted and clearly visible. The surgeons should trim their nails of hands and their main aim should be expertise, speed with efficiency, operation with minimum pain and proper marragement.

Hippocrates introduce a round cutting-saw called triphin for trephining in case of head injury with fracture of skull.

Regarding prognosis, he writes, "patients are not interesting on hearing the accounts of their illness, rather they want to know the prognosis or the furhere prospect of his illness. So the chinicians should be able to forecatst the prognosis." Some of his prognostic opinions are interesting:

(a) If the patient continues to be in sleep and his white sclera remain visible, lips are hanging, his body is cold and face becomes pale,then it is dangerous.

(b) If one utters meaningless words (delirium) with grinding of teeth in high fever, the prognosis is bad.

(C) If the eyes are sunken, nose erect, cheeks are sunken, ears are cold skin of the face is dry and coloured pale, then his death is near. Such a facies is still now is known as "Hippocratic face".

Hippocrates often asked for the examination of stool and urine. He often used to consider the dreams of the patient for his diagnosis. But these are not later found to be acceptable.

He did not prefer to use medicine in many cases and often used to say that . "Nature will cure. " This idea is the fore runner of the modern theory of body resistance in the form of natural and aquired immunity.

He used to advise moist fomenting of the body and light food for nutrition. He often used honey as a medicine, with vinegar in case of pain and with water in case of thirst. It is interesting to note that Allah has mentioned honey as cure of diseases in the Holy Quran. The most famous book of Hippocrates is Aphorism or saying. Some of them are :

Life is short, but the time to learn skill is long.

Danger is temporary. 
It is difficult to determine objective

If the delirious patient falls into sleep, it is a good omen.

Tiredness without any known cause is a sign of disease.

Fat people has more chance of sudden death than thin people.

If a patient of fetanus survives four days he will be cured.

Tuberculosis is common in 18-30 years range and mental illness during 40 to 60 years.

During early Muslim period (750-850 AC) many of his books were translated into Arabic.

His famous books are:-

Prognosticon, De morbis popularibus. Aphorism,De Natura hominis, De genitura, De Septimanis, Prognostica (De indicis mortis). De pustalis et apostematibus significantibus. mortem, opera varia and secrata etc.

Galen (130-199A.C) wrote commentary on many of the books of Hippocrates. The famous Arabic book Kitabul Hukama mentioned some of these books-kitab Ahade-Bukrat (Bukrat is Arabic version of Hippocrates), Kitabul Fusul, Kitabul kasar, Kitabul Amrad al Hada, Kitabul M'aye and Hawa and Kitab Tabiatul Insan etc.

\section{Plato (427-347 B.C.)}

Plato is known as Aflatun in the Muslim world. He was a philosopher. Diring his time medical science was mostly based on philosophical theories. He tried to compromise psychiatry with medical science. He did not contribute any thing important in medical science but his philosophy had great influence in the early Muslim period.

\section{Aristotle (384-322 B.C.)}

Aristotle was a disciple of Plato. Aristotle was known as Aristatalis in the Arab world. According to some scholars, he was probably the greatest scientific genious the world has ever seen. He was the master of all pre-Greek and Greek knowledge. King Alexander was his student who established a great empire by his sword. But it broke down soon after his death while Aristotle is still remembered as a great thinker and scientist. Though Aristotle was not a physician yet he introduced biology in the field of science. He began the comparative anatomy and introduced embryology in medical science.

He believed in the so-called four fluids of Hippocrates. He thought that Heart is the seat of knowledge and he believed that the arteies contain air. He dissected about fifty animals to learn anatomy but did not dissect human body. He, like Hippocrates supported abortion if the featus did not show sign of life.

Aristotle wrote many books and in Tarikhul Hukama the names of 105 of his books are mentioned.

Khalifa Al-Mamoon of Baghdad collected his books from Greece and enriched his library 


\section{Theophrastos (370-285 B.C.)}

He was a disciple of Plato and a colleague of Aristotle. He was not a physician but he introduced many medicinal plants and discussed biological science. In his book-Historia plantarum, he mentioned and described the physical aspects of about 500 plants and their usefulness as medicine. Because he described the different parts of plants he is regarded as the Founder of Botany.

He, unlike his teachers believed that Brain, not the heart is the seat of knowledge. His six books were translated into Arabic.

\section{Praxagoras of Cos (340 B.C.)}

Praxagoras was the inventor of pulse rate count in medical science. He also described the difference of artery and vein.

He used to practice unusual and many useless methods of treatment, all were later became out of use.

Before Theophrastos and Praxagoras, the following names are found in history of Greek medicine. Though their contributions are not so important, yet they were renowned in their own time.

1. Hermes the second

2. Hermes the third. He discovered bottle and big cups.

3. Polybos, a son-in-law of Hippocrates. His Arab name is Bulis.

4. Famlin-nothing is known about him.

5. Astafin-he was a physician in his time.

\section{Herophilus (300-250 B.C.)}

He was known as Herophilus of Chalcedon, an outskirt of modern Istambul, now known as Kadikoy.

According to some authorities, Herophilus dissected the dead bodies of human and animals. His contributions in describing the different parts and bones have given him the title of Father of Anatomy

His name is immortalised by giving the name of a part of the brain. Trocular Herophili. He declared that the brain is the centre of the Nervous system and the seat of intelligence and knowledge. Thus he discarded the wrong belief of Hippocrates. It is believed that he was the first person to dissect human dead body publicly.

\section{Erasistratus (304-260 B.C.)}

He is known as Arasteratis in Arab medical books. Erasistratus is said to be the Father of Physiology, while his contemporary Herophilus was the Father of Anatomy. He also dissected animal and human dead bodies. It is said that he used to collect the dead bodies of condemned prisoners. Erasistratus wrote a book on physiology at a time when medical science was based only on Anatomy. He also discarded the fluid theory of Hippocrates. He developed another wrong theory of 
vital spirit. He thought, air enters the blood in the heart and produces a pneuma. called vital spirit, which later enters the brain to produce Animal spirit.

From the experience of dissection of human body he thought that the Heart was the centre of all the arteries and veins.

Though Hirophilus and Erasistratus began dissection of human body, this practice was soon abandoned due to religions prejudice. This lead to many erontous theories in the medical science. Dissection of Human dead body began again by Mondino de Luzzi (1275-1326 A.C.) about 15 centuries later.

With the downfall of Greek civilization the medical science also became subject of regionalism and blind following of their teachers. Later on one group declared:"Where observation failed reason might surprise" This group was known as school of reasoning.

Another group was known as Dogmatists or Dogmatic school or Rationalists. Those who gave more importance on Anatomy were known as Anatomists or Anatomical school. The other groups were Methodists. Pnudmatists etc.

With the political fall of the Greeks, the civilization also became out of fashion.

- From Ali, A : বিজ্ঞানে মूসলমाনের দান, 8th part, Malik Library, Dhaka.

Health is the root of all happiness

- A Common Saying

To seek knowledge, go to (far-away country) China if necessary

Al-Hadis 